\title{
Interaction of White Rot Fungus [Sclerotinia sclerotiorum (Lib.) de Bary] and Root-Knot Nematode [Meloidogyne incognita (Kofoid and White) Chit.] in Cabbage (Brassica oleracea L.)
}

\author{
R. Kalaivanan*, M. Dhivya, G. Karthikeyan, K. Devrajan and K. Manonmani \\ Department of Plant Pathology, Agricultural College and Research Institute, Tamil Nadu \\ Agricultural University, Madurai- 625104, Tamil Nadu, India \\ *Corresponding author
}

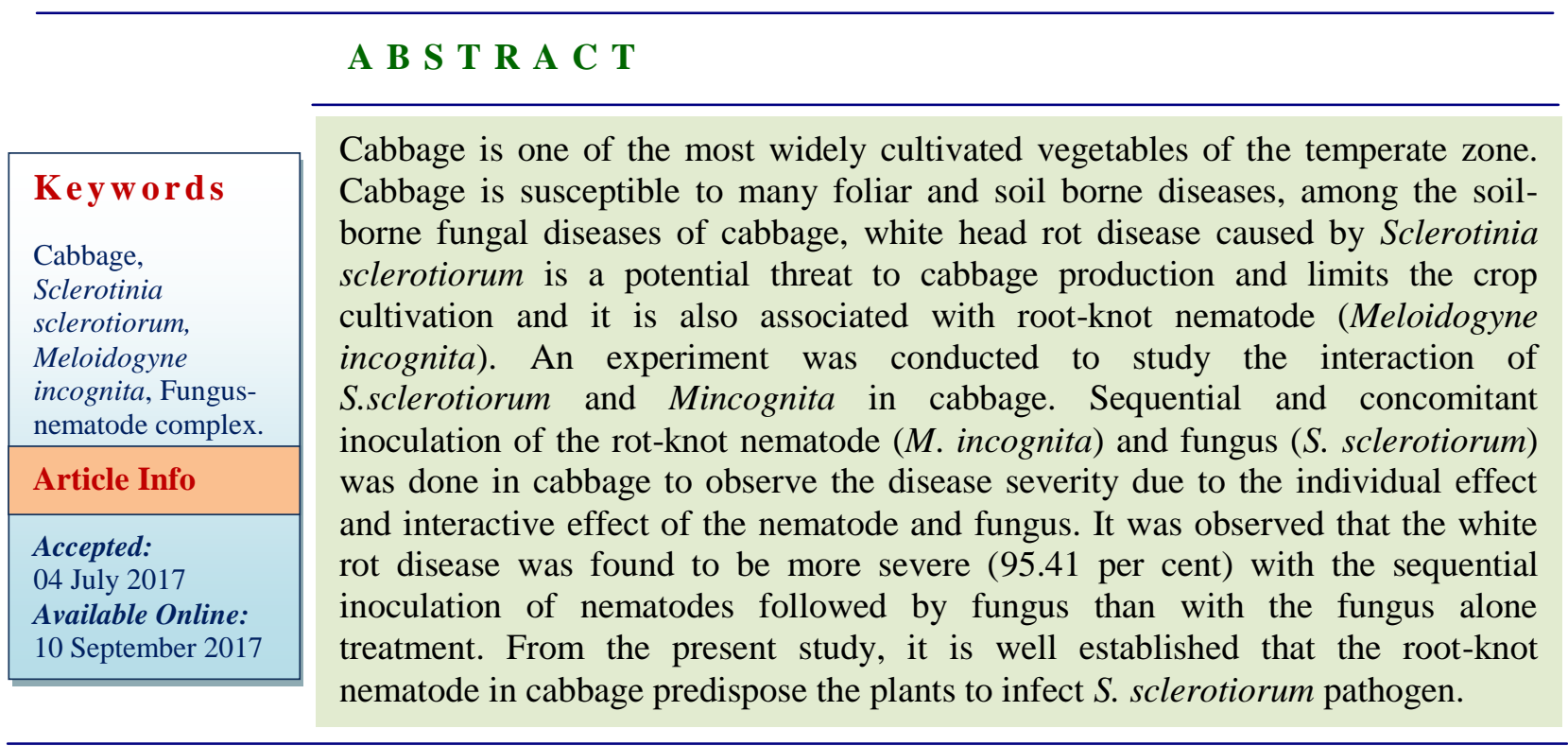

\section{Introduction}

Cabbage (Brassica oleracea L. or B. oleracea var. capitata L.) is one of the most widely cultivated vegetables of the temperate zone. It is a leafy green or purple biennial plant, grown as an annual vegetable crop for its dense-leaved heads. It is closely related to other Cole crops, such as Broccoli, Cauliflower and Brussels sprouts. Cabbage is one of the most popular cruciferous vegetables grown throughout India and is one of the richest sources of energy (Vitamin C) and health benefits
(Aggie Horticulture, 2013).It is susceptible to many foliar and soil borne diseases, among them white rot disease caused by Sclerotinia sclerotiorum is a potential threat to cabbage production and limits the crop cultivation and it is also associated with root-knot nematode, Meloidogyne incognita. The nematodes usually assist and enhance the pathogenicity mechanism of the fungus towards modifications in the host plant tissues (Jordan, 1987; Bowers et al., 1996). The disease intensity of many soil-borne fungal pathogens 
is aggravated by association with root-knot nematode especially Meloidogyne spp. (Golden and Van Gundy, 1975). Loganathan et al., (2010) reported the positive correlations between head rot disease intensity and population of root-knot nematode, $M$. incognita in cabbage. Interactive effect of disease intensity increases by population of root-knot nematode $M$. incognita and also reduces plant growth and seed yield of Plantago ovate (Anisha and Akhtar, 2012). Management of this disease is becoming very difficult due to its soil borne nature and complex with nematode.

\section{Materials and Methods}

\section{Source of root-knot nematode}

Cabbage roots infested with $M$. incognita were collected from the farmer's fields and the roots were examined for the presence of the nematode. A monoculture of $M$. incognita was raised in sterile soil on tomato plant under glasshouse conditions. The culture was checked periodically for its purity. Sterilized pot mixture $(500 \mathrm{~g})$ was taken in $15 \mathrm{~cm}$ diameter pots. The soil was inoculated with freshly hatched second stage juveniles of $M$. incognita@one juveniles/gm and on which seeds of cabbage were sown. Optimum watering was done every day and observation was made on 25th day after inoculation. The gall development was assessed using gall index scale developed by Headle et al., (1989). Observations on number of egg mass per gram root and gall index using 1-5 scale (Gall index: $1=$ no galls; $2=1-25 \%$ galls; $3=$ $26-50 \%$ galls; $4=51-75 \%$ galls; $5=76-100 \%$ galls per root system) were recorded.

\section{Source of Sclerotinia sclerotiorum}

Cabbage heads showing characteristic head rot symptoms were collected and the pathogen was isolated by tissue segment method (Yella Goud, 2011) on potato dextrose agar medium. Pure culture of the isolate was obtained by single hyphal tip method (Yella Goud, 2011). The morphological characters of the pathogen were observed under microscope and the pathogen was maintained on PDA slants at $4^{\circ} \mathrm{C}$.

The pathogenicity was proved by head detached technique on cabbage head under laboratory conditions, by making a hole using cork borer and pathogen was inoculated in to the hole and closed with wet absorbent cotton.

After 10 days of inoculation, the cabbage head was observed for rotting symptoms and sclerotial bodies (Siddique and Yasmin, 1998).

For soil inoculation, S. sclerotiorum was multiplied in sand-maize medium (Riker and Riker, 1936). The substrate containing $1900 \mathrm{~g}$ of sand and $100 \mathrm{~g}$ of maize powder (19:1) was mixed, moistened with $800 \mathrm{ml}$ of water $\mathrm{kg}^{-1}$ and packed in polypropylene bags.

The bags were autoclaved at $1.4 \mathrm{~kg} \mathrm{~cm}^{-2}$ for two hr for two consecutive days and each bag was inoculated with two $9 \mathrm{~mm}$ culture discs of the fungus. These bags were incubated at room temperature $\left(28 \pm 2^{\circ} \mathrm{C}\right)$ for 15 daysand the pathogenicity of the fungus was confirmed by Koch's postulates. Earthen pots of 30-cm-dia were filled with five $\mathrm{kg}$ of pot mixture (red soil : sand : FYM at 1:1:1 $\mathrm{w} / \mathrm{w} / \mathrm{w}$ ), sterilized at $1.4 \mathrm{~kg} \mathrm{~cm}^{-2}$ for two $\mathrm{h}$ for two successive days and inoculated by mixing $10 \mathrm{~g}$ of inoculum of the fungus multiplied on sand maize medium.

Cabbage seedlings were planted in pots and proper controls were also maintained. The pots were maintained in glasshouse by uniform and judicious watering. The plants were observed for development of disease symptoms. 
Interaction of Sclerotinia and Meloidogyne in cabbage

A pot culture experiment was conducted with six treatments each replicated four times in a completely randomized block design to study the interaction of root knot nematode and head rot pathogen in cabbage. Sterilized pot mixture was used to fill the $3 / 4$ dia mud pots. In each pot $10 \% \mathrm{w} / \mathrm{w}$ of fungus and 1500 juveniles of nematode were inoculated in each pot.

The treatments are as follows, $\mathrm{T}_{1}$ - Fungus alone@10\%w/w, $\mathrm{T}_{2}$ - Root knot nematode alone@1500 juveniles, $\mathrm{T}_{3}$ - Fungus was inoculated first and root knot nematode was inoculated after 7 days, $\mathrm{T}_{4}$ - Root knot nematode was inoculated first and fungus was inoculated after 7 days, $\mathrm{T}_{5}-$ Simultaneous inoculation of both fungus and root knot nematode, $\mathrm{T}_{6}-$ Control (Uninoculated). The inoculation of fungal pathogen and nematode was done as described above. The nematode root knot index and population of nematode were recorded on 45 DAI in concerned treatments. Infection on root and stem was recorded at $45 \mathrm{DAI}$ and the head rot disease incidence was recorded by Per cent infection. The plant growth parameters viz., germination percentage, plant height and plant biomass were also recorded in each treatment.

\section{Result and Discussion}

\section{Identification of Meloidogyne species associated with Cabbage}

Meloidogyne species collected from cabbage were identified by the presence of root galls (Picture a), and female egg $(b, c)$ in root portion and determining their morphological characters Mature females are pear-shaped, globose, 0.4-1.3 mm long, usually embedded in root tissue which is often swollen or galled, soft body, pearl-white in color, stylet is shorter, 10-24 $\mu \mathrm{m}$ under stereo microscope.
Identification of $S$. sclerotiorum associated with cabbage

The species was identified based on the morphological characters identification. Observation under microscope revealed hyaline, septate, branched and multinucleate hyphae (Picture e). Mycelium appeared as white to tan in culture (Picture f). No asexual conidia were observed. The sclerotia were black in colour, large in size and irregular in shape.

Effect of Sclerotinia sclerotiorum and Meloidogyne incognita in cabbage on head rot and gall index in cabbage

Sequential inoculation of nematodes 7 days prior to fungus inoculation significantly increased the severity of white head rot incidence to 95.4 per cent followed by the concomitant inoculation of nematode and fungus, which recorded a white rot incidence of 84.31 per cent, indicating that nematodes predispose plants to infection by fungus and aggravate the disease incidence, which ultimately leads to the death of plants. The nematode gall indices were found to be 4 and 3 in the above treatments, respectively. Highest gall index of 5.0 was observed when the nematode alone was inoculated. When the fungus alone was inoculated 75.4 per cent head rot incidence was observed. However, when fungus was inoculated 7 days prior to inoculation of nematode recorded a head rot incidence of 73.96 per cent and the nematode gall index was found to be 2 . When the number of egg masses were considered, a highest egg masses of 27.49/gram of root tissue was observed when the nematode was inoculated 7 days prior to fungus inoculation. However, a egg masses of 14.27/gram of root tissue was observed when the fungus was inoculated 7 days prior to nematode inoculation. A maximum egg masses of 24.52/gram root tissue was observed, when the nematode alone inoculated (Table 1). 
Effects of Sclerotinia sclerotiorum and Meloidogyne incognita on head rot disease severity and plant growth parameters of cabbage

In general all the plant growth parameters were decreased significantly in all the treatments when compared to uninoculated control. Sequential inoculation of nematodes 7 days prior to fungus inoculation significantly decreased the germination percentage with $53 \%$. The plant growth parameters viz., plant height and plant biomass were also recorded with $6.4 \mathrm{~cm}$ and $1.91 \mathrm{~g}$ respectively followed by the concomitant inoculation of nematode and fungus which recorded a germination percentage of $55.2 \%$, and a plant height and plant biomass of $6.8 \mathrm{~cm}$ and $1.97 \mathrm{~g}$ respectively. The reduction in plant growth parameters indicating that nematodes predispose plants to infect fungus and aggravate the disease incidence which ultimately leads to plants death (Table 2; Fig. 1).

Table.1 Effect of Meloidogyne incognita and Sclerotinia sclerotiorum on head rot and Gall in dexin cabbage

\begin{tabular}{|l|c|c|c|}
\hline \multicolumn{1}{|c|}{ Treatment(s) } & $\begin{array}{c}\text { Root gall index } \\
\mathbf{( 0 - 5} \text { scale) }\end{array}$ & $\begin{array}{c}\text { No. of eggs } \\
\text { mass/g of root }\end{array}$ & $\begin{array}{c}\text { Per cent white rot } \\
\text { disease incidence }\end{array}$ \\
\hline S. sclerotiorum alone @ 10\% w/w & $0(4.05)$ & 0 & $75.4(60.29)$ \\
\hline$M$. incognita alone @ 1500 juveniles/pot & $5(12.92)$ & 24.52 & $7.5(15.89)$ \\
\hline $\begin{array}{l}\text { Inoculation of S. sclerotiorum @ 10\% w/w 7days } \\
\text { prior to inoculation of M. incognita@ 1500 } \\
\text { juveniles/pot }\end{array}$ & $2(8.12)$ & 14.27 & $73.96(59.31)$ \\
\hline $\begin{array}{l}\text { Inoculation of } M . \text { incognita @ 1500 juveniles/pot } \\
\text { 7days prior to inoculation of S. sclerotiorum @ } \\
10 \% \text { w/w juveniles }\end{array}$ & $4(11.48)$ & 27.49 & $95.41(78.41)$ \\
\hline $\begin{array}{l}\text { Concomitant inoculation of S. sclerotiorum @ } \\
10 \% \text { w/w and M. incognita @ 1500 juveniles/pot }\end{array}$ & $3(9.97)$ & 21.94 & $84.31(66.7)$ \\
\hline Uninoculated control & $0(4.05)$ & 0 & $0(0.70)$ \\
\hline $\mathrm{CD}(\mathrm{P}=0.05)$ & 0.19 & 0.56 & 4.48 \\
\hline
\end{tabular}

Mean of Four replications

Values in parantheses are arc sine transformed values

Table.2 Effect of Meloidogyne incognita and Sclerotinia sclerotiorum on germination and Plant growth parameter of cabbage

\begin{tabular}{|l|c|c|c|}
\hline \multicolumn{1}{|c|}{ Treatment(s) } & $\begin{array}{c}\text { Germination } \\
(\%)\end{array}$ & $\begin{array}{c}\text { Plant } \\
\text { height } \\
\text { (cm) }\end{array}$ & $\begin{array}{c}\text { Plant } \\
\text { biomass } \\
\text { (grams) }\end{array}$ \\
\hline S. sclerotiorum alone @ 10\% w/w & $62 \%(51.94)$ & 7.4 & 2.23 \\
\hline M. incognita alone @ 1500 juveniles/pot & $63.8 \%(53.0)$ & 7.0 & 2.06 \\
\hline $\begin{array}{l}\text { Inoculation of S. sclerotiorum @ 10\% w/w 7days prior inoculation of M. } \\
\text { Incognita@ 1500 juveniles }\end{array}$ & $59.4 \%(50.42)$ & 7.1 & 1.91 \\
\hline $\begin{array}{l}\text { Inoculation of M. incognita @ 1500 juveniles/pot 7days prior to inoculation } \\
\text { of S. sclerotiorum @ 10\% w/w }\end{array}$ & $53 \%(46.71)$ & 6.4 & 1.75 \\
\hline $\begin{array}{l}\text { Concomitant inoculation of S. sclerotiorum @ 10\% w/w and M. incognita @ } \\
\text { 1500 juveniles/pot }\end{array}$ & $55 \%(47.87)$ & 6.8 & 1.97 \\
\hline Uninoculated control & $72 \%(58.05)$ & 9.9 & 3.60 \\
\hline CD (P=0.05) & 1.62 & 0.44 & 0.21 \\
\hline
\end{tabular}

Mean of four replications

Values in parentheses are arc sine transformed values 
Fig.1 a. Root-knot symptom in cabbage b. Egg masses of $M$. incognita on roots of cabbage c. Female nematode d. Symptom of head rot on cabbage e. mycelial characters of S. sclerotiorum $\mathrm{f}$.

Culture of S. sclerotiorumwith sclerotia

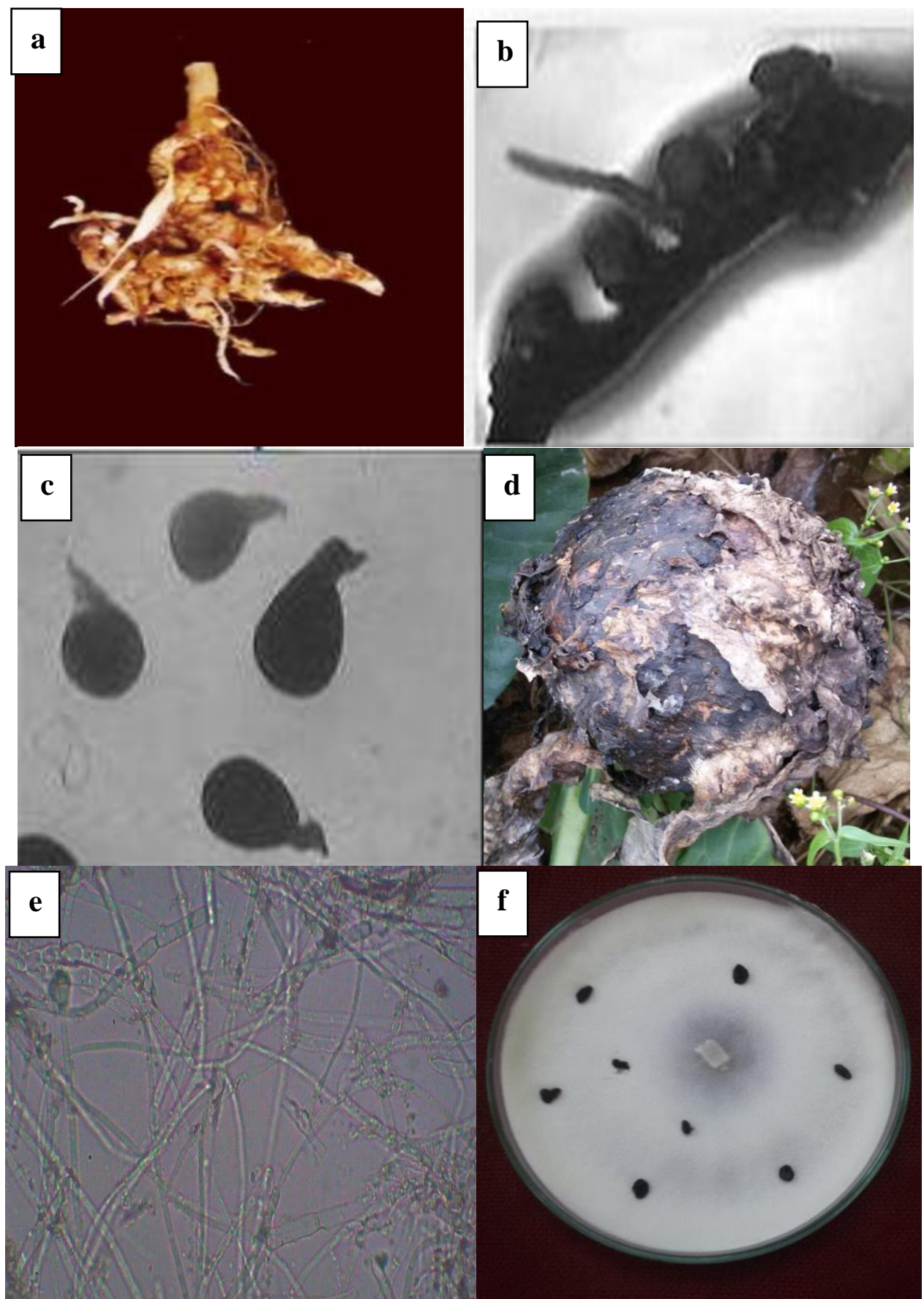

The diseased cabbage plants were collected from conventional cabbage growing areas of Tamil Nadu. The pathogenic isolates of $S$. sclerotiorum was established by the standard isolation procedure and the isolate possessed the morphological characters similar to $S$. sclerotiorum as described by Pedro et al., (2015), that the young growing mycelium was fluffy white. The black sclerotia were developed from the mycelium growing in 
strands at its tip initiates sclerotial formation and sclerotia were first white and becoming light brown to dark brown at maturity.

Nematode infected roots were collected and the juveniles were inoculated in the soil where tomato seedlings were planted to maintain the nematode population and gall formation was noticed in the inoculated plants as described by Meena et al., (2015) on cabbage.

When the pathogen was inoculated on the head of cabbage and incubated at 18 to $20^{\circ} \mathrm{C}$ for a week, rotting symptoms was observed and sclerotia were also developed on the head. It was commensurate with the findings of Siddiqui and Yasmin (1998). By inoculation of root-knot nematodes root galls were developed on the root of inoculated plant as reported by Sasanelli et al., (2013).

Many species of plant parasitic nematodes predispose the plants for infection by certain fungi or in same way enhance the severity of the diseases (Taylor, 1990; Abrantes et al., 1994; Jonathan and Rajendran, 1998). Wounding of hosts by nematode by predisposition, appears to have a restricted role in promoting interactions between nematode, $M$. incognita and soil borne pathogen, $S$. sclerotiorum (Anisha and Akhtar, 2012). Nematodes act as a predisposer in the spread of secondary fungal pathogens (Meena et al., 2015).

The above mechanism suggested that the nematode bring about severe host susceptibility for fungal infection. In a similar way, $M$. incognita would aggregate the head rot symptoms when the nematode was inoculated previously or simultaneously with fungal pathogen in cabbage. Loganathan et al., (2010) reported earlier that there was a positive correlation between white rot disease intensity and population of root-knot nematode $M$. incognita in cabbage.

\section{References}

Abrantes, I.M., N. Volvas, M.S.N. Santos and S.N. Sato. 1994. Meloidogyne arenaria and Plasmodiophora brassicae, causal agents of gall development on cabbage roots in the Republica Democratica DE SAO TOME principle. Nematol. Medit., 22: $115-118$.

Aggie Horticulture. Introduction to Cabbages and Celts. Texas A and M University. Retrieved 2013: 10-19.

Anisha Bano and Akhtar Haseeb. 2012. Interactive effect of Meloidogyne incognita and Sclerotinia sclerotiorum on disease development, plant growth and seed yield of Plantago ovate. Current Nematology, 23(1, 2): 23-28.

Delahaut, K.A., and A.C. Newenhouse. 1997. Growing broccoli, cauliflower, cabbage and other cole crops in wisconsm. National Agriculture Library.

Headle, C.M., B.D. Bruton and R.M. Davis. 1989. Influence of Glomus intraradices and soil phosphorus on Meloidogyne incognita infecting Cucumis melo. Journal of Nematology, 21(1): 69-73.

Jonathan, E.I., and G. Rajendran. 1998. Interaction of Meloidogyne incognita and Fusarium oxysporum f.sp. cubense on banana. Nematologia Mediterranea, 26: 9-12.

Loganathana, M., G.V. Siblea, S. Maruthasalama, D. Saravanakumara, T. Raguchandera, M. Sivakumar and R. Samiyappan, 2010. Trichoderma and chitin mixture based bioformulation for the management of head rot (Sclerotinia sclerotiorum (Lib.) deBary)-root-knot (Meloidogyne incognita Kofoid and White; Chitwood) complex diseases of cabbage. Archives of Phytopathology and Plant Protection, 43: 1011-1024.

Meena, S.K., S. A. Ramyabharathi, T. Raguchander and E. I. Jonathan. 2015. Meloidogyne incognita and Fusarium 
oxysporum interaction in Gerbera. African Journal of Microbiology Research, 9(18): 1281-1285.

Pedro, M., M.G., David Ruano-Rosa, Elisabetta Schiliro, Pilar Prieto, Cayo Ramos, Pablo Rodríguez-Palenzuela and Jesús Mercado-Blanco. 2015. Complete genome sequence of Pseudomonas fluorescens strain PICF7, an indigenous root endophyte from olive (Olea europaea L.) and effective biocontrol agent against Verticillium dahlia. Standards in Genomic Sciences, 10:10.

Ramsey, G.B., J.S. Wiant and G.K.K. Link. 1938. Market diseases of fruits and vegetables: Crcuifers and Cucurbits. U.S. Dept. Agric., 2: 92.

Riker, A.J., and R.S. Riker. 1936. Introduction to research on plant diseases. Johns Swift Co. Mc., New
York. p.177.

Sasanelli, N., N. Vovlas, N. Trisciuzzi, C. Cantalapiedra-Navarrete,

J.E. Palomares-Rius and P. Castillo. 2013. Pathogenicity and host-parasite relationships of Heterodera cruciferae in cabbage. Plant Dis., 97: 333-338.

Siddiqui, M., and A. Yasmin. 1998. Cabbage a new host of Sclerotinia sclerotiorum for Pakistan. Agronomie, 8(1): 85-87.

Taylor, 1990. A larval development test for the detection of anthelmintic resistance in nematodes of sheep. Research in Veterinary Science, 49(2): 198-202.

Yella Goud, T., 2011. Biofumigation in the management of stem rot and pod rot of Groundnut caused by Sclerotium rolfsii, M.Sc. (Ag.) Thesis, Acharya N G Ranga Agricultural University, Hyderabad.

\section{How to cite this article:}

Kalaivanan, R., M. Dhivya, G. Karthikeyan, K. Devrajan and Manonmani, K. 2017. Interaction of White Rot Fungus [Sclerotinia sclerotiorum (Lib.) de Bary] and Root-Knot Nematode [Meloidogyne incognita (Kofoid \& White) Chit.] in Cabbage (Brassica oleracea L.). Int.J.Curr.Microbiol.App.Sci. 6(9): 641-647. doi: https://doi.org/10.20546/ijcmas.2017.609.079 